\title{
Nasal cancer in the textile and clothing industries
}

\author{
LOUISE A BRINTON, W J BLOT, AND J F FRAUMENI JR \\ From the Environmental Epidemiology Branch, National Cancer Institute, Bethesda, MD, USA
}

ABSTRACT A case-control study of 160 patients with cancers of the nasal cavity and paranasal sinuses and 290 controls showed an excess risk associated with employment in the textile or clothing industries, with the increase (relative risk $[R R]=2 \cdot 1$ ) found only among female workers. There was, however, no increasing trend in risk with years of employment or duration since first exposure. Both male and female workers were at an increased risk of adenocarcinoma (RR $=2 \cdot 5$ ), with further enhancement of risks for those experiencing dusty work conditions. Although aetiological inferences cannot be drawn from this study, the finding of raised risk supports some previous observations and the need for further investigation of the cancer experienced by textile and clothing workers.

Although the aetiology of cancers of the nasal cavity and sinuses has not been well studied, the available evidence indicates that the tumour often results from occupational exposures. Many of these relations have been attributed to dusty working conditions, such as furniture manufacturing, ${ }^{1}$ nickel production, ${ }^{2-4}$ and the leather shoe industry. ${ }^{56}$ Of interest, therefore, are several observations of a raised risk of nasal cancer among workers in the textile industry ${ }^{7-10}$ where there is considerable exposure to dust.

To examine the relation of employment in the textile and clothing industries and the risk of nasal cancer, data from a case-control study in North Carolina and Virginia were analysed. The concentration of these industries in this region allowed examination of various specific exposures. In addition, this area has experienced high mortality rates for cancers of the nasal cavities and sinuses, particularly in women (see figure).

\section{Methods}

This case-control study included patients diagnosed with primary malignancies of the nasal cavity and sinuses (ICD-8 160.0; 160.2-160.5; 160.8-160.9) at four hospitals in North Carolina and Virginia between 1 January 1970 and 31 December 1980 . Cases were limited to those aged 18 or older who were residents of the state in which the admitting hospital was located. Control subjects came from

Received 6 February 1984

Accepted 13 August 1984 several sources: for each case determined to be alive at the time of interview (1980-2) two hospital controls were selected, matched to the case in hospital, year of admission ( \pm 2 years), age ( \pm 5 years), sex, race (white, other), and state economic area (or county, if possible) of usual residence. The controls had to be alive at the time of interview. Patients with a primary admission diagnosis of malignant neoplasms of the buccal cavity and pharynx (ICD-8 codes 140-149), oesophagus (150), nasal cavity, middle ear and accessory sinuses (160), larynx (161), or secondary neoplasms $(197.9,198.9)$; benign neoplasms of the respiratory system (212); mental disorders (290-315); acute sinusitis (503); deflected nasal septum (504); or nasal polyps (505) were excluded. For cases determined to be dead at the time of interview, two different controls were selected. One consisted of hospital controls derived in the same manner as above, except that they need not be alive. The other series consisted of dead individuals identified through state vital statistics offices. Matching criteria were similar to those used for living cases and included age ( \pm 5 years), sex, race, country of usual residence, and year of death.

A total of 193 cases, 232 hospital controls, and 140 death certificate controls were identified for study. Telephone interviews, from study subjects or their next of kin, averaged 30-40 minutes and focused on occupational exposures, medical and family history, smoking and alcohol consumption, and sociodemographic factors. Interviews were successfully conducted for 160 of the cases $(82.9 \%)$ and 290 controls $(78.0 \%)$ (178 hospital controls, 112 death certificate controls). Interviews were 


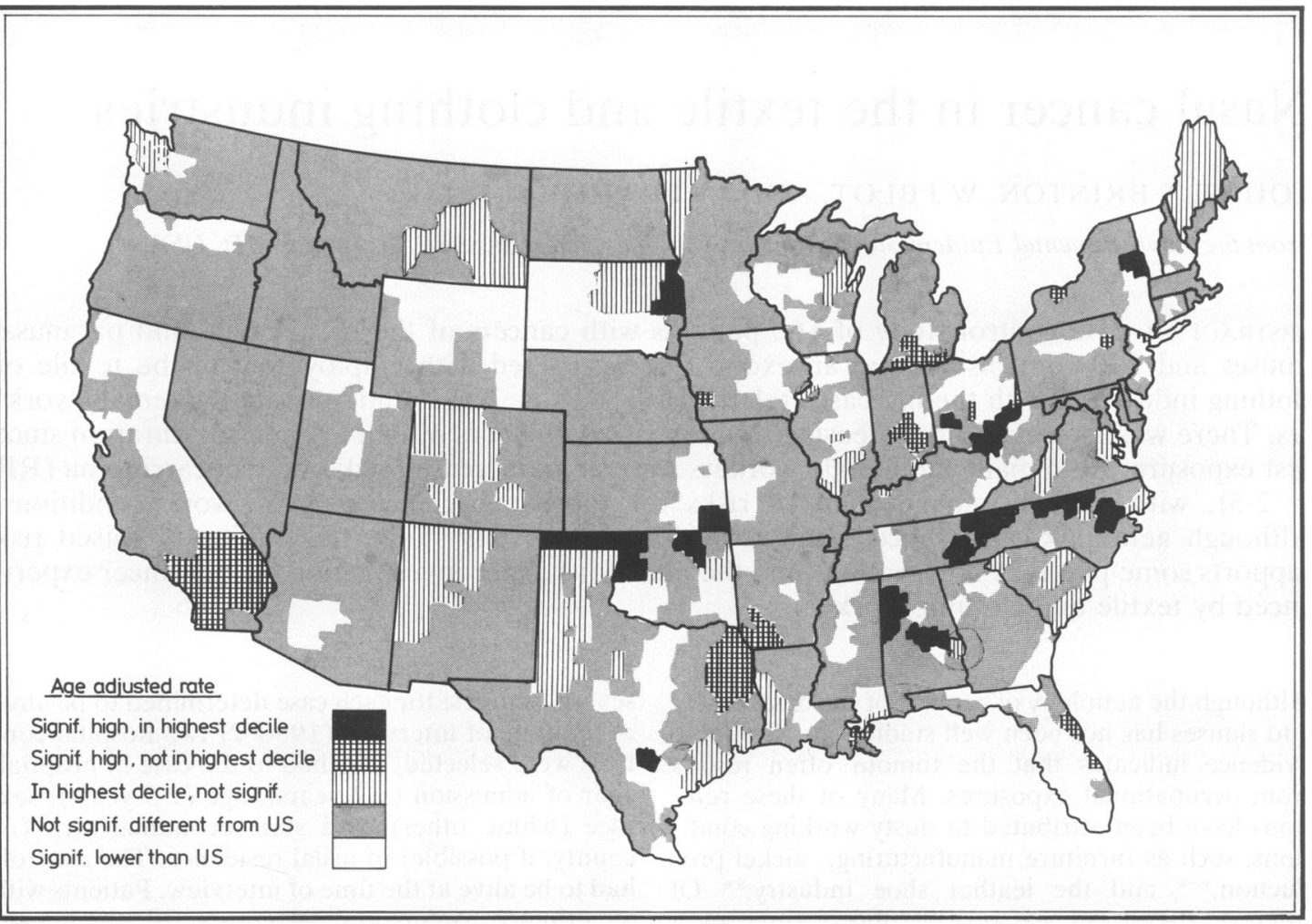

Cancer mortality 1950-69 by state economic area: nose, nasal cavities, and sinuses in white women.

obtained directly from study subjects for $32.5 \%$ of the cases and $39.3 \%$ of the controls. Reasons for non-response included refusal $(6.2 \%$ of cases $v$ $4.0 \%$ of controls), illness $(0.5 \% v 1.6 \%)$, inability to locate study subject or trace an eligible living respondent $(4.7 \% v 8 \cdot 1 \%)$, and lack of a telephone $(5.7 \% \vee 8.3 \%)$.

In addition to the interviews details of the disease were abstracted from medical records. This resulted in the classification of 86 squamous cell carcinomas; 24 adenocarcinomas or adenoid cystic carcinomas; 36 other carcinomas (five transitional cell, two mucoepidermoid, four anaplastic, six undifferentiated, and 19 otherwise unspecified carcinomas); and 14 other histological types (three malignant melanomas, five sarcomas, three esthesioneuroblastomas, one fibrous histiocytoma, one angiofibroma, and one lymphoma). In the analysis the two histological entities adenocarcinoma and adenoid cystic carcinoma were combined on the grounds that they are both rare non-squamous cell glandular tumours that appear to have similar natural histories. Additionally, there is no reason to suspect that they have different aetiologies, although there has been little mention of adenoid cystic tumours in previous studies. A total of 61 tumours arose in the nasal cavity, 71 in the maxillary sinuses, and 28 in other sinuses or in multiple sites.

The measure of association used for evaluating the effect of an exposure was the relative risk (RR) as approximated by the odds ratio. Confounding variables were evaluated by stratified techniques, with maximum likelihood estimates of combined ratios and $95 \%$ confidence intervals $(\mathrm{CI})$ derived. ${ }^{11}$ For multiple levels of exposure, significance was assessed using a one tailed linear trend test. ${ }^{12}$ Multivariate analyses using a disease probability logistic model were also used to control simultaneously for various potential confounding variables. ${ }^{13}$

Since matching was used in the study design, analyses were also conducted using a logistic approach for matched data. ${ }^{14}$ The results were similar to those derived from the unmatched, stratified analyses. Since the matched analyses required elimination of unmatched elements and presented difficulties in interpreting results according to specific histologies, 
Table 1 Relative risks of cancers of the nasal cavity and sinuses by employment in the textile or clothing industries

\begin{tabular}{|c|c|c|c|c|}
\hline $\begin{array}{l}\text { No employed in textiles or } \\
\text { clothing industries }\end{array}$ & Cases & Controls & $R R$ & (95\% Confidence interval) \\
\hline $\begin{array}{l}\text { Men: } \\
\text { No } \\
\text { Yes }\end{array}$ & $\begin{array}{l}81 \\
12\end{array}$ & $\begin{array}{r}155 \\
28\end{array}$ & $\begin{array}{l}1 \cdot 00 \\
0 \cdot 82\end{array}$ & $\overline{(0 \cdot 4-1 \cdot 7)}$ \\
\hline $\begin{array}{l}\text { Women: } \\
\text { No } \\
\text { Yes }\end{array}$ & $\begin{array}{l}45 \\
22\end{array}$ & $\begin{array}{l}87 \\
20\end{array}$ & $\begin{array}{l}1 \cdot 00 \\
2 \cdot 13\end{array}$ & $\overline{(1 \cdot 1-4 \cdot 3)}$ \\
\hline $\begin{array}{c}\text { Total: } \\
\text { No } \\
\text { Yes }\end{array}$ & $\begin{array}{r}126 \\
34\end{array}$ & $\begin{array}{r}242 \\
48\end{array}$ & $\begin{array}{l}1 \cdot 00 \\
1.32\end{array}$ & $\overline{(0 \cdot 8-2 \cdot 2)}$ \\
\hline
\end{tabular}

Total relative risk is adjusted for sex.

analyses disregarding the individual matching were chosen for presentation.

\section{Results}

A total of $14.5 \%$ of the male and $24.1 \%$ of the female study subjects reported employment in the textile or clothing industries (table 1 ). The overall RR, adjusted for sex, was $1.3(95 \%$ CI $0.8-2 \cdot 2)$, but among the men fewer cases than controls had been employed in the textile or clothing industries $(\mathrm{RR}=$ $0 \cdot 8$ ) whereas among the women, significantly more cases than controls reported such employment (RR $=2 \cdot 1,1 \cdot 1-4 \cdot 3)$. Although various other risk factors were found for nasal cancer in this study, ${ }^{15}$ none exerted any confounding influences on these associations, including smoking or snuff taking; employment in industries involving wood dust, chemicals, or chromates; and a history of nasal polyps, recurrent nose bleeds, or sinus trouble. In addition, the results did not vary according to source of information (direct or next of kin interview).
Table 2 examines further details regarding employment in the textile or clothing industry. No clear relation of risk was observed according to duration of employment. Most of the women worked for less than 10 years, and these short term workers were at higher risk $(3.9,1.4-11.0)$ than those who worked 10 years or more $(1 \cdot 4,0 \cdot 5-3 \cdot 8)$. Furthermore, there was no evidence of an increase in risk with years since initial employment, either for men or for women. Among women, a significant rise in risk $(5 \cdot 8)$ was observed for those first employed less than 20 years before diagnosis, most of whom began work in the 1960 s or later, but those employed earlier showed no significant excess risk. These women typically began work at older ages, resulting in a nearly linear increase in risk with age at first employment, reaching a non-significant risk of 3.9 for those employed at age of $\mathbf{3 0}$ or later. The risk was raised $(2.3,0.9-5.5)$ for women employed in occupations involving exposure to dust.

Table 3 gives details regarding the employment histories of male and female cases. The nature of

Table 2 Relative risks of cancers of the nasal cavity and sinuses by employment in the textile or clothing industries. (Numbers of cases given in parentheses)

\begin{tabular}{|c|c|c|c|}
\hline Employment parameters & Men & Women & Total \\
\hline Never employed & $1 \cdot 00(81)$ & $1.00 \quad(45)$ & $1.00 \quad(126)$ \\
\hline $\begin{array}{l}<10 \\
\geqslant 10 \\
\text { Unknown }\end{array}$ & $\begin{array}{l}0.55(4) \\
1.49(7) \\
0.38(1)\end{array}$ & $\begin{array}{l}3 \cdot 87^{*}(12) \\
1 \cdot 35 \quad(7) \\
1 \cdot 45 \quad(3)\end{array}$ & $\begin{array}{ll}1.50 & (16) \\
1.42 & (14) \\
0.85 & (4)\end{array}$ \\
\hline $\begin{array}{l}\text { Years since initial employment: } \\
<20 \\
20-39 \\
\geqslant 40 \\
\text { Unknown }\end{array}$ & $\begin{array}{l}0.96(3) \\
1.91(8) \\
0.21(1) \\
0.00(0)\end{array}$ & $\begin{array}{l}5 \cdot 80^{*}(9) \\
1 \cdot 38 \quad(5) \\
1 \cdot 50 \quad 7) \\
1.93(1)\end{array}$ & $\begin{array}{l}2 \cdot 51^{*}(12) \\
1.67(13) \\
0.83(8) \\
0.32(1)\end{array}$ \\
\hline $\begin{array}{l}\text { Age at first employment: } \\
<20 \\
20-29 \\
\geqslant 30 \\
\text { Unknown }\end{array}$ & $\begin{array}{l}0.77(4) \\
0.96(4) \\
1.53(4) \\
0.00(0)\end{array}$ & $\begin{array}{l}1.55 \\
2.26 \\
3.87 \\
1.93 \quad(6)\end{array}$ & $\begin{array}{l}1 \cdot 14 \quad(12) \\
1.50 \quad(11) \\
2 \cdot 39 \quad 10) \\
0.32(1)\end{array}$ \\
\hline $\begin{array}{l}\text { Dust exposure: } \\
\text { No } \\
\text { Yes } \\
\text { Unknown }\end{array}$ & $\begin{array}{l}0.48(3) \\
1.22(7) \\
0.77(2)\end{array}$ & $\begin{array}{ll}1 \cdot 69 & (7) \\
2 \cdot 28 & (13) \\
3 \cdot 87 & (2)\end{array}$ & $\begin{array}{ll}0.95 & (10) \\
1.72 & (20) \\
1.28 & (4)\end{array}$ \\
\hline
\end{tabular}

Total relative risks are adjusted for sex.

${ }^{*} \mathrm{p}<0.05$. 
Table 3 Occupational details regarding employment in the textile or clothing industries for patients with cancer of the nasal cavity a paranasal sinuses

\begin{tabular}{|c|c|c|c|c|c|c|c|c|c|}
\hline $\begin{array}{l}\text { Yr of } \\
\text { birth }\end{array}$ & $\begin{array}{l}\text { Entry to } \\
\text { industry }\end{array}$ & $\begin{array}{l}\text { Yr left } \\
\text { industry }\end{array}$ & $\begin{array}{l}\text { Year of } \\
\text { diagnosis }\end{array}$ & $\begin{array}{l}\text { Nature of } \\
\text { industry }\end{array}$ & $\begin{array}{l}\text { Occupation in } \\
\text { industry }\end{array}$ & $\begin{array}{l}\text { Dust } \\
\text { exposure }\end{array}$ & $\begin{array}{l}\text { Origin of } \\
\text { dust }\end{array}$ & Histology & Site \\
\hline $\begin{array}{l}1911 \\
1918\end{array}$ & $\begin{array}{l}1942 \\
1965\end{array}$ & $\begin{array}{l}1970 \\
1972\end{array}$ & $\begin{array}{l}1970 \\
1973\end{array}$ & $\begin{array}{l}\text { Cotton mill } \\
\text { Sleeping bag } \\
\text { company }\end{array}$ & \begin{tabular}{l}
\multicolumn{1}{c}{ Men } \\
Folder/rag packer \\
Trimmer/sweeper/ \\
weaver/dyer
\end{tabular} & $\begin{array}{l}\text { Yes } \\
\text { Yes }\end{array}$ & $\begin{array}{l}\text { Lint, dust } \\
\text { Cloth }\end{array}$ & $\begin{array}{l}\text { Squamous } \\
\text { Squamous }\end{array}$ & $\begin{array}{l}\text { Max sinu抢 } \\
\text { Max sinus }\end{array}$ \\
\hline $\begin{array}{l}1923 \\
1914 \\
1938 \\
1907\end{array}$ & $\begin{array}{l}1948 \\
1949 \\
1959 \\
1923\end{array}$ & $\begin{array}{l}\text { Unknown } \\
1970 \\
1959 \\
1943\end{array}$ & $\begin{array}{l}1973 \\
1970 \\
1975 \\
1974\end{array}$ & $\begin{array}{l}\text { Carpet plant } \\
\text { Clothing } \\
\text { Clothing } \\
\text { Textiles }\end{array}$ & $\begin{array}{l}\text { Scarrer } \\
\text { Trimmer } \\
\text { Cloth spreader } \\
\text { Weaver/fixer/ } \\
\text { foreman }\end{array}$ & $\begin{array}{l}\text { Yes } \\
\text { Yes } \\
\text { Yes } \\
\text { No }\end{array}$ & $\begin{array}{l}\text { Unknown } \\
\text { Cotton } \\
\text { Lint }\end{array}$ & $\begin{array}{l}\text { Squamous } \\
\text { Adenocarcinoma } \\
\text { Adenoid cystic } \\
\text { Squamous }\end{array}$ & $\begin{array}{l}\text { Cavity 을 } \\
\text { Cavity 요 } \\
\text { Other sinus } \\
\text { Other sinus }\end{array}$ \\
\hline $\begin{array}{l}1903 \\
1918 \\
1916 \\
1941 \\
1931 \\
1933\end{array}$ & $\begin{array}{l}1932 \\
1937 \\
1949 \\
1961 \\
1950 \\
1952\end{array}$ & $\begin{array}{l}1947 \\
1956 \\
1954 \\
1974 \\
1950 \\
1971\end{array}$ & $\begin{array}{l}1970 \\
1974 \\
1979 \\
1979 \\
1975 \\
1976\end{array}$ & $\begin{array}{l}\text { Textiles } \\
\text { Cotton mill } \\
\text { Textiles } \\
\text { Nylon company } \\
\text { Hosiery } \\
\text { Textiles }\end{array}$ & $\begin{array}{l}\text { Worked with velvet } \\
\text { Oiler/spinner/dyer } \\
\text { Weaver } \\
\text { Operator } \\
\text { Factory worker } \\
\text { Weaving machine } \\
\text { fixer Women }\end{array}$ & $\begin{array}{l}\text { Unknown } \\
\text { Yes } \\
\text { No } \\
\text { Unknown } \\
\text { No } \\
\text { Yes }\end{array}$ & Cotton & $\begin{array}{l}\text { Neoplasm, NOS } \\
\text { Carcinoma, NOS } \\
\text { Squamous } \\
\text { Adenocarcinoma } \\
\text { Squamous } \\
\text { Adenoid cystic }\end{array}$ & 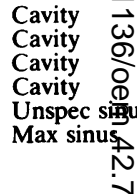 \\
\hline $\begin{array}{l}1893 \\
1924 \\
1899 \\
1937 \\
1913 \\
1934\end{array}$ & $\begin{array}{l}1909 \\
1970 \\
1916 \\
1958 \\
1930 \\
1959\end{array}$ & $\begin{array}{l}1912 \\
1972 \\
1920 \\
1964 \\
1937 \\
1962\end{array}$ & $\begin{array}{l}1970 \\
1974 \\
1972 \\
1975 \\
1978 \\
1972\end{array}$ & $\begin{array}{l}\text { Textiles } \\
\text { Textiles } \\
\text { Cotton mill } \\
\text { Textiles } \\
\text { Hosiery mill } \\
\text { Cotton mill }\end{array}$ & $\begin{array}{l}\text { Mill worker } \\
\text { Inspector } \\
\text { Sweeper } \\
\text { Loom operator } \\
\text { Looper } \\
\text { Thread machine } \\
\text { operator }\end{array}$ & $\begin{array}{l}\text { No } \\
\text { No } \\
\text { Yes } \\
\text { Yes } \\
\text { No } \\
\text { Yes }\end{array}$ & $\begin{array}{l}\text { Cotton, lint } \\
\text { Lint, dust } \\
\text { Thread, } \\
\text { cotton }\end{array}$ & $\begin{array}{l}\text { Squamous } \\
\text { Adenocarcinoma } \\
\text { Angiofibroma } \\
\text { Adenoid cystic } \\
\text { Squamous } \\
\text { Squamous }\end{array}$ & $\begin{array}{l}\text { Max sinus } \\
\text { Other sinus } \\
\text { Max sinuş } \\
\text { Max sinu@ } \\
\text { Cavity } \\
\text { Max sinus }\end{array}$ \\
\hline $\begin{array}{l}1928 \\
1906\end{array}$ & $\begin{array}{l}1962 \\
1922\end{array}$ & $\begin{array}{l}1969 \\
1965\end{array}$ & $\begin{array}{l}1980 \\
1975\end{array}$ & $\begin{array}{l}\text { Clothing } \\
\text { Cotton mill }\end{array}$ & $\begin{array}{l}\text { Presser } \\
\text { Operator-automatic } \\
\text { washer }\end{array}$ & $\begin{array}{l}\text { No } \\
\text { Yes }\end{array}$ & Cotton & $\begin{array}{l}\text { Squamous } \\
\text { Squamous }\end{array}$ & $\begin{array}{l}\text { Max sinuš } \\
\text { Max sinus }\end{array}$ \\
\hline $\begin{array}{l}1897 \\
1921 \\
1894 \\
1907 \\
1915\end{array}$ & $\begin{array}{l}1926 \\
1942 \\
1910 \\
1940 \\
1934\end{array}$ & $\begin{array}{l}1961 \\
1976 \\
1954 \\
1941 \\
1974\end{array}$ & $\begin{array}{l}1977 \\
1976 \\
1971 \\
1970 \\
1978\end{array}$ & $\begin{array}{l}\text { Hosiery mill } \\
\text { Hosiery mill } \\
\text { Textiles } \\
\text { Cotton mill } \\
\text { Clothing }\end{array}$ & $\begin{array}{l}\text { Folder } \\
\text { Inspector } \\
\text { Cleaner } \\
\text { Unknown } \\
\text { Seamstress/ } \\
\text { dressmaker }\end{array}$ & $\begin{array}{l}\text { No } \\
\text { Yes } \\
\text { Yes } \\
\text { Unknown } \\
\text { No }\end{array}$ & $\begin{array}{l}\text { Lint } \\
\text { Cotton }\end{array}$ & $\begin{array}{l}\text { Transitional cell } \\
\text { Squamous } \\
\text { Squamous } \\
\text { Squamous } \\
\text { Carcinoma, NOS }\end{array}$ & $\begin{array}{l}\text { Cavity } ~ \\
\text { Cavity } \\
\text { Cavity } \\
\text { Other sings } \\
\text { Max sinu衣 }\end{array}$ \\
\hline $\begin{array}{l}1908 \\
1940 \\
1917 \\
1885\end{array}$ & $\begin{array}{l}1967 \\
1964 \\
1950 \\
\text { Unknown }\end{array}$ & $\begin{array}{l}\text { Unknown } \\
1973 \\
1952 \\
\text { Unknown }\end{array}$ & $\begin{array}{l}1979 \\
1974 \\
1973 \\
1974\end{array}$ & $\begin{array}{l}\text { Clothing } \\
\text { Textiles } \\
\text { Hosiery mill } \\
\text { Hosiery mill }\end{array}$ & $\begin{array}{l}\text { Presser } \\
\text { Seamstress } \\
\text { Unknown } \\
\text { Ran winder/ } \\
\text { inspector }\end{array}$ & $\begin{array}{l}\text { No } \\
\text { Yes } \\
\text { Unknown } \\
\text { Yes }\end{array}$ & $\begin{array}{l}\text { Cotton } \\
\text { Unknown }\end{array}$ & $\begin{array}{l}\text { Carcinoma, NOS } \\
\text { Squamous } \\
\text { Squamous } \\
\text { Adenocarcinoma }\end{array}$ & $\begin{array}{l}\text { Other sings } \\
\text { Cavity } \frac{2}{8} \\
\text { Max sinu官 } \\
\text { Max sinus }\end{array}$ \\
\hline 1920 & 1944 & 1980 & 1980 & $\begin{array}{l}\text { Hosiery/ } \\
\text { clothing }\end{array}$ & Seamstress & Yes & $\begin{array}{l}\text { Nylon, } \\
\text { cotton }\end{array}$ & Adenocarcinoma & Other sin \\
\hline $\begin{array}{l}1948 \\
1929 \\
1926\end{array}$ & $\begin{array}{l}1968 \\
1975 \\
1943\end{array}$ & $\begin{array}{l}1978 \\
1980 \\
1968\end{array}$ & $\begin{array}{l}1978 \\
1980 \\
1980\end{array}$ & $\begin{array}{l}\text { Hosiery mill } \\
\text { Clothing } \\
\text { Textiles/yarn }\end{array}$ & $\begin{array}{l}\text { Folder/seamer } \\
\text { Asst manager } \\
\text { Operator-roving } \\
\text { frame/winder }\end{array}$ & $\begin{array}{l}\text { Yes } \\
\text { Yes } \\
\text { Yes }\end{array}$ & $\begin{array}{l}\text { Lint } \\
\text { Lint } \\
\text { Cotton }\end{array}$ & $\begin{array}{l}\text { Rhabdomyosarcoma } \\
\text { Squamous } \\
\text { Esthesio- } \\
\text { neuroblastoma }\end{array}$ & $\begin{array}{ll}\text { Cavity } & \stackrel{2}{7} \\
\text { Cavity } & \stackrel{0}{\circ} \\
\text { Cavity } & \stackrel{0}{\circ}\end{array}$ \\
\hline 1956 & 1975 & 1977 & 1980 & $\begin{array}{l}\text { Silkscreen } \\
\text { factory }\end{array}$ & Printer & Yes & Wood & Osteosarcoma & Max sin \\
\hline
\end{tabular}

Max $=$ Maxillary. NOS $=$ Not otherwise specified.

specific industries and occupations showed a fair amount of heterogeneity. The industries primarily included textile and cotton mills, clothing manufacturing, and hosiery. No specific occupations predominated, although weavers, winding operators, trimmers, and seamstresses were well represented. The primary origin of dust was cotton, although other substances (lint, nylon, wood) were mentioned.

Further analyses related work in the textile industry to tumour histology (table 4). Among women, the risk was highest for adenocarcinoma $(R R=2 \cdot 5$, 0.7-9.0), although there was a non-significant excess risk $(R R=1 \cdot 9-2 \cdot 2)$ for the other tumours. A higher risk of adenocarcinoma $(R R=2 \cdot 5,0 \cdot 7-8 \cdot 3)$ among textile workers was also noted for men. The risk for adenocarcinomas among both men and women was highest when dusty working conditions were reported, being $4.7(1 \cdot 2-17 \cdot 8)$ in men and 3.4 $(0 \cdot 8-14 \cdot 1)$ in women.

No significant associations were observed according to site of the tumour, with the occupational risks being 1.5 for nasal cavity, 1.2 for maxillary sinus, and 1.7 for other sinus cancers.

Associations with employment in the textile or clothing industries were also examined according to the levels of other nasal cancer risk factors. The increased risk among women was not differentially affected by smoking (RRs of 1.8 and 2.2 for smokers and non-smokers, respectively). Similarly, snuff 
Table 4 Relative risks of nasal cancer histologies by employment in the textile or clothing industries. (Numbers of cases given in parentheses)

\begin{tabular}{|c|c|c|c|}
\hline $\begin{array}{l}\text { Employed in textiles } \\
\text { or clothing }\end{array}$ & $\begin{array}{l}\text { Squamous cell } \\
(n=86)\end{array}$ & $\begin{array}{l}\text { Adenocarcinoma } \\
(n=24)\end{array}$ & $\begin{array}{l}\text { Other } \\
(n=50)\end{array}$ \\
\hline \multicolumn{4}{|l|}{ Men: } \\
\hline No & $1.00(47)$ & $1.00(9)$ & $1.00(25)$ \\
\hline $\begin{array}{c}\text { Yes } \\
\text { Women. }\end{array}$ & $0.71(6)$ & $2.46(4)$ & $0.44(2)$ \\
\hline \multicolumn{4}{|l|}{ Women: } \\
\hline No & $1.00(22)$ & $1.00(7)$ & $1.00(16)$ \\
\hline \multirow{2}{*}{\multicolumn{4}{|c|}{$\begin{array}{l}\text { Yes } \\
\text { Total: }\end{array}$}} \\
\hline & & & \\
\hline No & $1.00(69)$ & $1 \cdot 00(16)$ & $1.00(41)$ \\
\hline Yes & $1 \cdot 24(17)$ & $2.47(8)$ & $1.06(9)$ \\
\hline
\end{tabular}

Total relative risks are adjusted for sex.

usage did not appear to modify the textile/clothing associations. Among women, the highest risks were observed among textile workers without prior sinus trouble $(R R=3 \cdot 0,1 \cdot 2-7 \cdot 4)$ or nasal polyps $(2 \cdot 3$, $1 \cdot 1-4 \cdot 8)$, although the detection of associations in the other subgroups was limited by small numbers of individuals with prior medical conditions. Employment in other high risk industries, including the manufacturing of furniture and other wood products, and exposure to chemicals and chromates, did not substantially alter the associations with exposures in the textile/clothing industries.

\section{Discussion}

This case-control study provided limited evidence that exposures in the textile or clothing industries increase the risk of nasal cavity and sinus cancers. Overall, employment in the industry was associated with a $32 \%$ excess risk, with only women being adversely affected $(\mathrm{RR}=2 \cdot 1)$. This finding may account for the high rates of nasal cancer reported among women in those counties of North Carolina and Virginia where a high percentage of residents have been employed in the textile industry. When histological types of nasal cancer were evaluated, both men and women were found to be at increased risk of nasal adenocarcinoma $(R R=2 \cdot 5)$. Textile exposures have been suggested previously as a risk factor for nasal cancer in studies from several other countries, including England, ${ }^{78}$ Sweden, ${ }^{10}$ and Finland, ${ }^{16}$ although the specific occupations have varied. In England one survey showed an increased incidence of nasal cancer among male upholsterers, tailors, and dressmakers but not textile workers. ${ }^{8}$ Bross et al, however, noted an excess of nasal cancer in New York among men employed as operatives in the textile mill industry. ${ }^{9}$ Corresponding information among women is largely unavailable, although one survey in Finland showed an excess risk of nasal cancer for knitters, ${ }^{16}$ an occupation where working conditions in the home apparently resemble those experienced in many industrial settings (H S R Malker, personal communication). Engzell et al also reported a high proportion of textile workers among women with squamous cell and poorly differentiated nasal carcinomas, ${ }^{10}$ although exposure details were limited and the absence of a control group prevented risk estimation.

The reason for the association with employment in the textile or clothing industries, notably among women in our study, is uncertain, especially since no relation existed with years of employment or time since first exposure. The fact that those first employed in later periods were at the highest risk suggests either the influence of a recently introduced agent or some promotional effect, but such relations were not hypothesised before the start of the study. Although it has been suggested that exposure to formaldehyde in the textile industry might increase the risk of nasal cancer, ${ }^{17}$ few individuals in our study reported such exposure ( 2 cases and 10 controls), and it was actually associated with a nonsignificant decrease in risk $(R R=0.4)$. Instead, the excess risk associated with employment in the textile industry seemed more closely related to occupations with significant exposure to dust. In our survey most subjects reported exposure to cotton dust. although contact with other substances was also noted. The association with cotton dust may merely reflect the widespread nature of this industry in states where the study was conducted, but a large proportion of cases in the survey of Acheson et al also reported exposure to cotton dust. ${ }^{7}$

It is noteworthy that exposure to dust in the textile or clothing industry primarily increased the risk of nasal adenocarcinomas, although there was some excess risk of other tumours in women. Similarly, employment in industries involving exposure to wood dust, notably in furniture making, raises the risk of nasal adenocarcinomas. ${ }^{15618}$ In several investigations heavy exposure to wood dust has been shown to decrease mucociliary clearance ${ }^{19}$ and produce other disturbances in the upper airway. ${ }^{20}$ 
Chronic nasal mucosal changes have also been documented among workers at a nickel refinery. ${ }^{21}$

In summary, our study provided some evidence for an association between employment in the textile industry and the risk of nasal cancer, but the findings to date are not definite. Arguing against an association is a recent proportional mortality study in female textile workers in North Carolina that failed to show an increased frequency of nasal cancer. ${ }^{22}$ If, however, as indicated in our study, the raised risks pertain mainly to adenocarcinomas or to workers with substantial exposure to dust, or both, cohort approaches may fail to have sufficient power to detect raised risks of nasal cancer. Future investigations should thus focus not only on the nature of the textile exposures but also on disease characteristics (such as histological types and precursor lesions) to help delineate possible carcinogens and mechanisms of action.

\section{References}

' Rang EH, Acheson ED. Cancer in furniture workers. Int J Epidemiol 1981;10:253-61.

${ }^{2}$ Doll R, Morgan LG, Speizer FE. Cancers of the lung and nasal sinuses in nickel workers. $\mathrm{Br} J$ Cancer 1970;24:623-32.

${ }^{3}$ Pedersen E, Hogetveit AC, Andersen A. Cancer of respiratory organs among workers at a nickel refinery in Norway. Int $J$ Cancer 1973;12:32-41.

${ }^{4}$ Enterline PE, Marsh GM. Mortality among workers in a nickel refinery and alloy manufacturing plant in West Virginia. $J N C I$ 1982;68:925-33.

${ }^{5}$ Acheson ED. Nasal cancer in the furniture and boot and shoe manufacturing industries. Prev Med 1976;5:295-315.

- Cecchi F, Buiatti E, Kriebel D, Nastasi L, Santucci M. Adenocarcinoma of the nose and paranasal sinuses in shoemakers and woodworkers in the province of Florence, Italy (1963-77). Br J Ind Med 1980;37:222-5.

7 Acheson ED, Cowdell RH, Rang E. Adenocarcinoma of the nasal cavity and sinuses in England and Wales. $\mathrm{Br} \mathrm{J}$ Ind Med 1972;29:21-30.

${ }^{8}$ Acheson ED, Cowdell RH, Rang EH. Nasal cancer in England and Wales: an occupational survey. $\mathrm{Br} J$ Ind Med 1981;38:218-24.

"Bross IDJ, Viadana E, Houten L. Occupational cancer in men exposed to dust and other environmental hazards. Arch Environ Health 1978;33:300-7.

${ }^{10}$ Engzell U, Englund A, Westerholm P. Nasal cancer associated with occupational exposure to organic dust. Acta Otolaryngol 1978;86:437-42.

"Gart JJ. Point and interval estimation of the common odds ratio in the combination of $2 \times 2$ tables with fixed marginals. Biometrika 1970;57:471-5.

12 Mantel N. Chi-square tests with one degree of freedom, extensions of the Mantel-Haenszel procedure. Journal of the American Statistical Association 1963;58:690-700.

${ }^{13}$ Breslow N, Powers N. Are there two logistic regressions for retrospective studies? Biometrics $1978 ; 34: 100-5$.

${ }_{14}$ Lubin J. A computer program for the analysis of matched casecontrol studies. Computers and Biomedical Research 1981;14:138-43.

is Brinton LA, Blot WJ, Becker JA, et al. A case-control study of cancers of the nasal cavity and paranasal sinuses. Am J Epidemiol 1984;119:896-906.

${ }^{16}$ Tola S, Hernberg S, Collan Y, Linderborg H, Korkala M. A case-control study of the etiology of nasal cancer in Finland. Int Arch Occup Environ Health 1980;46:79-85.

17 Halperin WE, Goodman M, Stayner L, Elliott LJ, Keenlyside RA, Landrigan PJ. Nasal cancer in a worker exposed to formaldehyde. JAMA 1983;249:510-2.

${ }^{18}$ Ironside P, Matthews J. Adenocarcinoma of the nose and paranasal sinuses in woodworkers in the state of Victoria, Australia. Cancer 1975;36:1115-21.

${ }^{19}$ Black A, Evans JC, Hadfield EH, Macbeth RG, Morgan A, Walsh M. Impairment of nasal mucociliary clearance in woodworkers in the furniture industry. Br J Ind Med 1974;31:10-7.

${ }^{20}$ Andersen HC, Andersen I, Solgaard J. Nasal cancers, symptoms and upper airway function in woodworkers. $\mathrm{Br} J$ Ind $\mathrm{Med}$ 1977;34:201-7.

${ }^{21}$ Torjussen W, Solberg LA, Hogetveit AC. Histopathological changes of the nasal mucosa in active and retired nickel workers. Br J Cancer 1979;40:568-80.

${ }^{22}$ Delzell E, Grufferman S. Cancer and other causes of death among female textile workers, 1976-78. JNCI 1983;71:73540. 